\title{
Systematic review of surgical procedures used in the treatment of aortic pathology in Mexico
}

\author{
Luis Barragán-Galindo, Alejandra Soto-Pérez, Javier E. Anaya-Ayala, Ramón García-Alva,
} César Cuen-Ojeda and Carlos A. Hinojosa*

Secretaría de Salud, Instituto Nacional de Ciencias Médicas y Nutrición "Salvador Zubirán", Dirección de Cirugía, Sección de Angiología y Cirugía Vascular, Ciudad de México, Mexico

\begin{abstract}
Introduction: In Mexico, there are no appropriate statistical data on aortic disease, which can be treated with medical management or open or endovascular surgical approach. Objective: To carry out a systematic search and review of the literature in electronic databases with regard to invasive management of aortic pathology in Mexico. Method: A systematic search and narrative review of available literature was carried out using different electronic databases: PubMed, Imbiomed, Clinical Key, Bibliat, Scielo, Sage Journals and Science direct, as well as with the Google Scholar search engine. Results: Ninety articles were found, out of which only 53 met the inclusion criteria. Observational studies and case reports were selected, emphasizing on patient demographics, clinical results, and 30-day postoperative survival. Conclusion: An elevated rate of complications is reported for aortic pathologies due to underdiagnosis, which results in management being more complicated and prognosis unfavorable. The creation of a national aortic disease registry is crucial to standardization in the approach and optimization of outcomes.
\end{abstract}

KEY WORDS: Mexico. Aorta. Aneurysms. Coarctation. Trauma. Aortic dissection.

\section{Introduction}

Aortic diseases are part of the wide spectrum of arterial pathologies such as aortic aneurysms, pseudoaneurysm, aortic rupture, inflammatory conditions, genetic diseases and acute aortic syndromes.

In Mexico, currently there are no adequate statistics on aortic disease because it is underdiagnosed and causes of death are often attributed to other pathologies. Timely diagnosis is on the rise thanks to the new minimally-invasive diagnostic methods and the new deliberate search programs. ${ }^{1}$

For treatment, medical management, or open or endovascular surgical approach are the possible options. Open surgery has been the treatment standard for various aortic pathologies with high morbidity and mortality. Although minimally-invasive procedures have gradually displaced open surgery, the latter remains necessary in some aortic pathologies and for the management of complications that may arise from endovascular treatment.

Aortic aneurysm is defined as a focal dilation of the aorta that exceeds $50 \%$ of its normal diameter and it results from progressive weakening of its walls; if it involves all three wall layers (tunica intima, tunica media and tunica adventitia) it is considered a true aneurysm; pseudoaneurysms are formed as a result of an injury in the aortic wall, where extraluminal blood flow remains in the surrounding tissue. Its most common location (90\%) is the abdominal aorta, specifically at its infrarenal portion. The most important risk factors include male gender, age older than 65 years, smoking, family history, hypertension and dyslipidemias. The most serious complication is aneurysm rupture, associated with a mortality rate of $80 \%$.

On the other hand, dissection is defined as the separation of aortic wall layers. Tears in the vessel intima can cause the dissection to expand, both proximally and distally, given that blood occupies the space
Correspondence:

${ }^{*}$ Carlos Hinojosa

E-mail: carlos.a.hinojosa@gmail.com
Date of reception: 24-05-2018

Date of acceptance: 24-11-2018

DOI: 10.24875/GMM.M19000245
Gac Med Mex. 2019;155:124-130

Contents available at PubMed www.gacetamedicademexico.com 


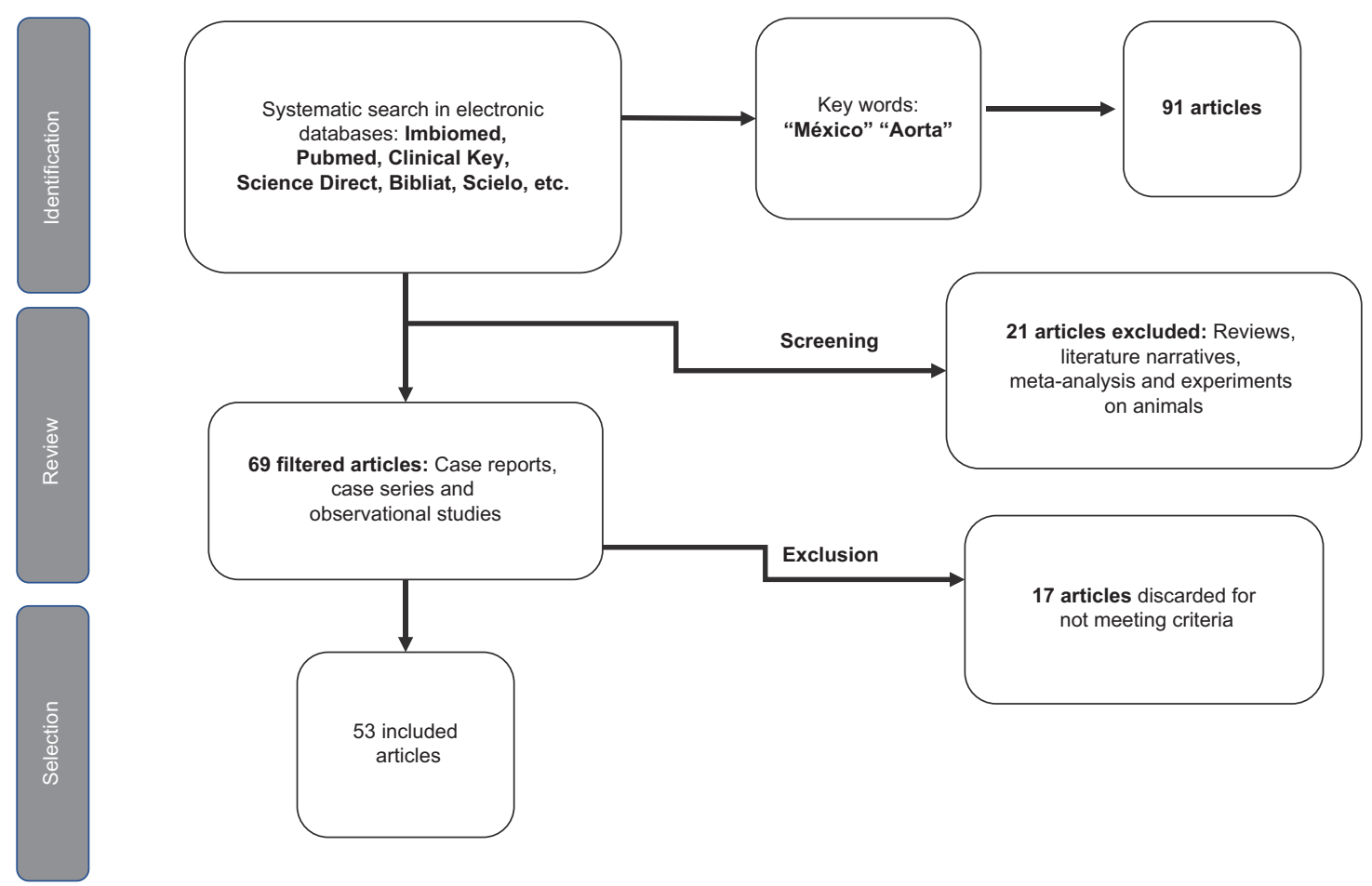

Figure 1. Flow-chart. Systematic search for literature on aortic pathology.

between the tunica intima and the tunica media. Despite technological advances in diagnostic and therapeutic methods, mortality associated with this this pathology remains high. Aortic dissections are due both to genetic and environmental factors and their prevalence is higher in patients with connective tissue disorders, systemic hypertension, congenital aortic stenosis or bicuspid aortic valve.

Coarctation of the aorta is characterized by abnormal thickening of the tunica media and intimal hyperplasia. It accounts for up to $7 \%$ of congenital heart diseases, with a prevalence of 0.2 per 1000 live births and a male-female ratio of 2:1. Often it affects the posterior wall at the origin of the subclavian artery, mainly the distal aortic arch and at the descending aorta root. Similarly, it is accompanied by cardiac anomalies, such as bicuspid aortic valve, patent ductus arteriosus or ventricular septum defects and is one of the anomalies commonly found in genetic syndromes, such as Turner's. ${ }^{2}$

Finally, vascular trauma has become a critical health problem. It can be encompassed mainly in traffic accidents or injuries generated by violence, which represent the leading causes of death in the young population. ${ }^{3}$ Aortic injury due to blunt trauma and deceleration is the second most common cause of death due to severe traffic accidents. Aortic rupture can occur at any level of the thoracic aorta, although it is less common in the abdominal aorta. ${ }^{4}$ Timely diagnosis and treatment are essential for survival. Endovascular treatment is an excellent alternative because it reduces morbidity, mortality, surgical time and in-hospital stay. ${ }^{5}$

\section{Method}

A systematic search was carried out in the PubMed (www.ncbi.nlm.nih.gov/pubmed), Imbiomed (www.imbiomed.com.mx), Clinical Key (www.clinicalkey.com), Bibliat (www.bibliat.unam.mx/es/), Scielo (www.scielo.org), Sage Journals (www.journals.sagepub.com) and Science direct (www.sciencedirect.com) electronic databases and with the Google Scholar search engine. The terms "Mexico" and "aorta" were used as keywords.

Figure 1 outlines the systematic literature review process. Only articles published in Mexico were selected, with those related to aortic valve disease being excluded.

\section{Results}

In the 50 selected articles, 1383 patients were identified. The works were grouped according to the type of aortic pathology, and the statistics descriptive 
analysis was classified into two groups: observational studies and case reports. The section "other aortic pathologies" was added, because not enough studies of some pathologies were found to perform individual analyses.

\section{Aortic aneurism}

Thirteen observational articles were reviewed, which included patients with thoracic and abdominal aortic aneurysm. Descriptive statistics was carried out, with standard deviations and means being determined. The results were weighted according to the number of patients per article (Table 1). Total number of patients included in the articles was 418 , with a mean age of 64 years; $78 \%$ of patients were males and $80 \%$ were managed with open surgery; 30 -day survival was $78 \%$. $6-18$

Case reports were also analyzed, divided according to the location of the aneurysm (Table 2) ${ }^{19-29}$ Reports were found of five patients with aneurysms of the abdominal aorta, in whom average age was 70 years and $60 \%$ were males; $60 \%$ were electively treated with the endovascular approach, with a 30-day survival of $80 \%$. Case reports were found of six patients with thoracic aorta aneurysms; mean age was 55 years and $83 \%$ were males; $72 \%$ were electively treated using the endovascular approach, with a 30-day survival of $83 \%$.

Figure $2 \mathrm{~A}$ shows the three-dimensional reconstruction of an angiotomography of a patient with an aneurysm of the infrarenal aorta.

\section{Coarctation of the aorta}

Eight observational publications corresponding to coarctation of the aorta were found (Table 1). ${ }^{30-37}$ Seven hundred and sixty-one patients were quantified, with a mean age of 13 years, and with $70 \%$ corresponding to the male gender. As for treatment, $58 \%$ were operated using the endovascular approach. Mean transcoarctation gradient was specifically assessed in this pathology, both prior and after the intervention. Mean pressure gradient prior to treatment was $27 \mathrm{mmHg}$, whereas post-treatment it was 6 mmHg. Mean 30-day survival was $95 \%$.

For the descriptive statistics of case reports (Table 2), ${ }^{38-43}$ the same variables were used. Six reports were found, where average age was 17 years and 50 $\%$ of patients were males. Half of them received endovascular treatment. As in the observational studies, the transcoarcation gradient was analyzed, with pre and post-treatment mean values of $69 \mathrm{mmHg}$ and 8 $\mathrm{mmHg}$, respectively, being found. No deaths were reported within the first 30 days after treatment. ${ }^{38-43}$

The open surgical procedure for coarctation of the aorta is shown in Figure 2B.

\section{Other aortic pathologies}

Observational studies and case reports of the following pathologies were analyzed: acute aortic syndromes, Takayasu arteritis, aortic dissections, congenital malformations, tumors with vascular involvement, aortic trauma and fistulas. They were grouped in the same category because of the paucity of works that have been published in Mexico on these subjects. The descriptive statistics of the most representative articles are detailed in Table 1.,44-49

The research that included the largest number of patients was conducted by Guering, ${ }^{44}$ where the records of 94 patients with acute aortic syndromes (penetrating ulcers, intramural hematomas, complicated dissections and aortic transections) were reviewed. The endovascular approach was used in $67 \%$ of patients, with a 30 -day survival of $79 \%$.

The only article identified on aortic dissection included 10 patients with Marfan syndrome and type B dissections, who were openly intervened, with 30-day postoperative survival of $89 \%$ (Figure $2 \mathrm{C}$ ). ${ }^{45}$

Two observational studies related to vascular trauma were found, which included four patients with a mean age of 34 years; two were males. All patients suffered closed trauma with involvement of the thoracic aorta; half of them underwent endovascular intervention. There were no deaths within the first 30 postoperative days. ${ }^{4,49}$

In Hinojosa's work, two patients with Takayasu arteritis are referred to have developed middle aortic syndrome as a complication, which has a reported prevalence of $0.000001 \%$ in patients with said pathology. The patients' mean age was 37 years, and both were females. They were approached with open surgery and 30 -day survival was $100 \%$. Figure 2D shows a three-dimensional reconstruction of the angiotomography of one of the patients mentioned in the article. ${ }^{46}$

Case reports were found on aortic fistulas, vascular trauma and congenital vascular pathologies (Table 2). ${ }^{5,50-55}$ 
Table 1. Observational studies on invasive treatment of different aortic pathologies

\begin{tabular}{|c|c|c|c|c|c|c|}
\hline Article number & Author & Patients (n) & Males (\%) & Mean age (\%) & Open approach (\%) & 30 -day survival (\%) \\
\hline \multicolumn{7}{|c|}{ Aortic aneurism } \\
\hline 1 & Rojas $(1996)^{6}$ & 31 & 90.30 & 64.7 & 100 & 76.90 \\
\hline 2 & Mendoza $(2001)^{7}$ & 20 & 75 & 67.8 & 100 & 100 \\
\hline 3 & Rojas $(2002)^{8}$ & 75 & 88 & 68.61 & 100 & 66 \\
\hline 4 & Ramírez $(2004)^{9}$ & 4 & 100 & 62.5 & 100 & 50 \\
\hline 5 & González (1996)10 & 20 & 20 & 71 & 100 & 10 \\
\hline 6 & Álvarez $(2002)^{11}$ & 101 & 74.20 & 69.1 & 100 & 72 \\
\hline 7 & Marquina $(2008)^{12}$ & 54 & 75.90 & 71.9 & 35.18 & 94.70 \\
\hline 8 & Serrano $(2003)^{13}$ & 6 & 33.30 & 41 & 100 & 100 \\
\hline 9 & Rodríguez (2011)14 & 12 & 83.30 & 57.8 & 0 & 100 \\
\hline 10 & Fink $(2002)^{15}$ & 31 & 90.30 & 69.1 & 0 & 96.80 \\
\hline 11 & Ramírez $(2003)^{16}$ & 39 & 82.05 & 47 & 100 & 89.80 \\
\hline 12 & Careaga $(2009)^{17}$ & 2 & 100 & 11 & 100 & 100 \\
\hline 13 & Galicia $(2010)^{18}$ & 23 & 83 & 46 & 83 & 87 \\
\hline Total & & 418 & $77.99 \%$ & $64.6 \pm 17.4$ & 80.4 & 78.05 \\
\hline \multicolumn{7}{|c|}{ Coarctation of the aorta } \\
\hline 1 & González (2006) ${ }^{30}$ & 7 & 85.70 & 24 & 0 & 100 \\
\hline 2 & Uruchurtu $(1999)^{31}$ & 6 & 83.30 & 27.1 & 0 & 100 \\
\hline 3 & Munayer $(2002)^{32}$ & 272 & 73.50 & 8.1 & 0 & 98.50 \\
\hline 4 & Fink $(2002)^{33}$ & 4 & 100 & 23.1 & 0 & 100 \\
\hline 5 & Hernández (2003) ${ }^{34}$ & 58 & 75.80 & 7 & 70 & 94.93 \\
\hline 6 & Márquez (2015) ${ }^{35}$ & 166 & 71 & 18 & 36.70 & 100 \\
\hline 7 & Zabal $(2003)^{36}$ & 32 & 63 & 24.00 & 0 & 100 \\
\hline 8 & Cervantes $(2006)^{37}$ & 216 & 61 & 13 & 100 & 86.20 \\
\hline Total & & 761 & 69.4 & $12.9 \pm 7.9$ & 41.72 & 95.16 \\
\hline \multicolumn{7}{|c|}{ Other aortic pathologies } \\
\hline 1 & Espinoza $(2013)^{4}$ & 2 & 0 & 37.5 & 100 & 100 \\
\hline 2 & Guering $(2015)^{44}$ & 94 & 74 & 50.9 & 33.00 & 78.80 \\
\hline 3 & Hinojosa $(2015)^{46}$ & 2 & 0 & 37.5 & 100 & 100 \\
\hline 4 & Guering $(2013)^{45}$ & 10 & 60 & 35.1 & 100 & 88.90 \\
\hline 5 & Mijangos $(2015)^{47}$ & 5 & 60 & 5.6 & 100 & 80 \\
\hline 6 & Herrera $(2011)^{48}$ & 3 & 100 & 28.5 & 100 & 66.60 \\
\hline 7 & Fink $(2002)^{49}$ & 2 & 100 & 34 & 0 & 100 \\
\hline
\end{tabular}

Mean age of the three patients reported with aortic fistulas was 66 years; $66 \%$ were males. All were treated with open surgery. Two patients had cavoaortic fistulas, one as a consequence of a retroperitoneal intervention due to trauma and the other due to aneurysm of the abdominal aorta. There was one case of aortogastric fistula caused by an ulcer. Thirty-day survival was $100 \%$. 
Table 2. Isolated case reports on invasive treatment of different aortic pathologies

\begin{tabular}{|c|c|c|c|c|c|}
\hline Pathology & Reports (n) & Mean age & Males (\%) & Open approach (\%) & 30-day survival (\%) \\
\hline Aneurisms of the abdominal aorta ${ }^{19-23}$ & 5 & 70 & 60 & 40 & 80 \\
\hline Aneurisms of the thoracic aorta ${ }^{24-29}$ & 6 & 55 & 83.30 & 16.70 & 83.30 \\
\hline Coarctation of the aorta ${ }^{38-43}$ & 6 & 17 & 50 & 50 & 100 \\
\hline Aortic fistulas ${ }^{50-52}$ & 3 & 66 & 66 & 100 & 100 \\
\hline Vascular trauma ${ }^{5,53,54}$ & 3 & 26.33 & 0 & 33 & 100 \\
\hline Congenital aortic pathologies ${ }^{55}$ & 1 & 4 & 0 & 100 & 100 \\
\hline
\end{tabular}

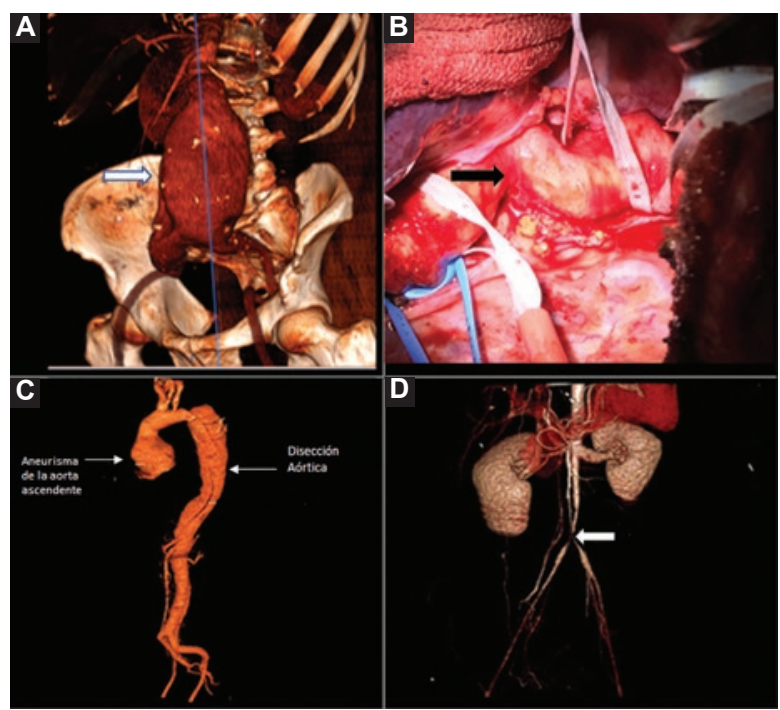

Figure 2. A) Aneurism of the abdominal aorta in the infrarenal portion. B) Coarctation of the aorta repair intraoperative picture. C) Descending aorta dissection. D) Abdominal aorta stenosis in a patient with Takayasu arteritis (figure 2D taken from reference 46 ).

Three cases of vascular trauma were identified, all of the female gender. Mean age was 26 years. Two patients with injuries in the abdominal aorta were treated with the endovascular approach and one with injury in the thoracic aorta was treated with open surgery. No deaths were reported.

Finally, a case was reported of a four-year-old girl with a congenital vascular ring in the thoracic aorta who was treated with open surgery and whose postoperative evolution was favorable.

\section{Discussion}

Knowledge and timely diagnosis of aortic pathology in Mexico have increased in the past few years due to the implementation and gradual increase of screening programs at different institutes and health care centers around the country. However, it is necessary to generate broader and better programs aimed at identifying a larger number of individuals at risk, in order to solve the population demand.

Even when aortic aneurysm continues to be the most common aortic pathology, we identified that a larger number of patients with coarctation of the aorta have been studied in Mexico; the patients included in this review account for $54.9 \%$ of total patients, while patients with aortic aneurysms account for $30.15 \%$.

With regard to the surgical management of the analyzed aortic pathologies, $51.97 \%$ of patients were treated with open surgery, and the rest was managed using an endovascular approach.

Although in our analysis only 30-day postoperative survival was taken into account, postsurgical complications are mentioned in some of the included studies. In the group of patients treated with open surgery, renal vein injury, retroperitoneal hematoma, acute kidney injury, respiratory failure and ischemic stroke are referred. On the other hand, in the group of endovascular approach, the most common complications were vascular perforation, ischemic stroke and thrombosis at the entry point.

The 30-day mortality rate of patients undergoing surgery was $12.33 \%$. The pathology with the highest rate was aortic aneurysm, with $21.8 \%$.

Owing to its high population density and the coverage shortage in the systems for early detection and timely treatment, it is expected that a significant percentage of these aortic pathologies will continue to be underestimated and underdiagnosed in Mexico.

\section{Conclusion}

Aortic pathology remains an important cause of morbidity and mortality in Mexico, and the training of more specialists with adequate surgical skills on these pathologies and their complications is therefore necessary. 
Moreover, we consider that the training of doctors who are not specialists in angiology and vascular surgery on the knowledge and diagnosis of aortic pathologies would be highly useful for the detection of the disease at early stages.

As for the field of clinical research, aortic pathology represents an area of opportunity in Mexico. We consider that the creation of a national registry of aortic disease would be relevant to the optimization of clinical results. For this reason, we can conclude that promoting the growth of research would be essential, in order to integrate an accurate knowledge of these pathologies and this way offer the most opportune treatment for each one of them.

\section{References}

1. Martínez-Hernández H. Los aneurismas de la aorta torácica y su enfoque terapéutico. Arch Cardiol Mex. 2006;76:S124-S133.

2. Márquez-González H, De León Mena S, Yáñez-Gutiérrez L, López-Gallegos D, Camargo-Zetina CO, Ortiz-Vázquez IC, et al. Complicaciones tardías de tratamiento de coartación aórtica: estudio mexicano de cohorte con más de 10 años de seguimiento. Rev Mex Cardiol. 2015;26:169-173.

3. Castañeda-Gaxiola, R. El problema del trauma vascular en México. Cir Gen. 2000;22:254-256.

4. Espinoza HJD, Nina VO, Venegas GU, Marroquín RR, Villarreal RCB, Molina E. Ruptura traumática de aorta torácica. Reporte de dos casos. Rev Latinoam Cir. 2013;3:47-50.

5. Kalach-Mussali AJ, Montes-Corrales BS, Vázquez-Minero JC. Diagnóstico oportuno de la disección de aorta por traumatismo contuso. Neumol Cir Torax. 2013;72:223-228.

6. Rojas, GA, Cervantes, J, Arcos, L, Guibovich, V, Colin, V. Aneurismas de la aorta abdominal. Cinco años de experiencia en el hospital American British Cowdray. Rev Mex Angiol. 1996;24:34-39.

7. Mendoza-Cortés A, Rodríguez-Trejo JM, Escotto-Sánchez I, Flores-PadiIla CM, Montuy-Vidal MA, Sulvarán-Aguilar A, et al. Abordaje retroperitoneal en aneurismas de aorta abdominal. Rev Mex Angiol. 2001;29:5-14

8. Rojas GA, Cervantes J, Torrontegui Á. Análisis de resultados en cirugía de aneurismas de aorta abdominal. Experiencia de 32 años. Rev Mex Angiol. 2002;30:38-42.

9. Ramírez-González AH, Corona-Murguía A, Murillo-Estrada D, Moreno-López M, Pérez-Villagómez Y, Tinoco-Pérez S, et al. Aneurisma roto de aorta abdominal. Experiencia en Uruapan Michoacán. Rev Mex Angiol. 2004;32:126-131

10. González LG, Sánchez C, Martínez CM. Aneurismas de aorta abdomina rotos: dos años de experiencia. Rev Mex Angiol. 1996:24:55-58.

11. Álvarez Tostado-Fernández $F$, Martínez Hernández-Magro P, Villanueva-Sáenz E. Colitis isquémica en pacientes sometidos a cirugía de reemplazo aórtico. Factores de riesgo. Rev Gastroenterol Mex. 2002:67:171-178

12. Marquina ME, Rodríguez TJM, Escotto SI, Rodríguez N, Morales GLG Espinosa APA. Complicaciones en el tratamiento de aneurisma de aorta abdominal infrarrenal del adulto mayor. Rev Mex Angiol. 2008;36:126-134.

13. Serrano CA, Martínez C, Sánchez B, García J, Vera O, Jiménez J. Experiencia quirúrgica con los aneurismas de aorta abdominal en el síndrome de Marfan. Rev Mex Angiol. 2003;31:13-17.

14. Rodríguez-Ortega F, Hernández-Mercado MA, Reyes-Corona JA, Gómez-Ríos N, Jaymes-Nuñez A, Alegría-Gardía H, et al. Tratamiento endovascular del aneurisma de aorta abdominal. Cir Gen. 2011;33:43-47.

15. Fink JG, Gutiérrez VS, Dena EE, Hurtado LLM, Zaldivar RFR. Tratamiento endovascular del aneurisma de aorta abdominal en pacientes mayores a 60 años: morbimortalidad perioperatoria. Cir Gen. 2002;24:34-39.

16. Ramírez-Vargas AF, Careaga-Reyna G, Téllez-Luna S, Argüero-Sánchez R. Tratamiento quirúrgico de los aneurismas de la aorta torácica. Rev Mex Cardiol. 2003:14:118-127.

17. Careaga.Reyna G, Ramírez-Vargas AF, Martínez Hernández-Magro R, Argüero-Sánchez R. Aneurisma de la aorta torácica en coartación aórtica sin cirugía previa. Presentación de dos casos. Cir Ciruj. 2009;77:61-63.

18. Galicia-Tornell MM, Marín-Solís B, Fuentes-Orozco C, Martínez-Martínez M, Villalpando-Mendoza E, Ramírez-Orozco F. Procedimiento de Bentall en la enfermedad aneurismática de la aorta ascendente: mortalidad hospitalaria. Cir Cir. 2010;78:45-51.

19. Soto-Hernández G, Alvarado-Lezama J, Bizueto-Rosas H, Madrid-Mier E, Martínez-Maya H, Mejía-Valero SA. Síndrome aortoduodenal secundario a un aneurisma de la aorta abdominal roto contenido. Rev Mex Angiol. 2014;42:95-101

20. Morales-Victorino N, García-López S, Alcántara-Meléndez MA, Herrera-Gomar M, Guering-Eid L, González-Chon O. Reparación endovascular de aneurisma abdominal. Rev Invest Med Sur Mex. 2011:18:179-182.

21. Lacayo M, Lecuona N, Córdova P, Flores, S, Cárdenas, Á. Tratamiento endovascular de Aneurisma de Aorta abdominal en el Hospital General de México. Rev Med Hosp Gen Mex. 2016;79:161-164.

22. Candia-De la-Rosa RF, Córdova-González I, Rodríguez-Esqueda M, Rico-Olvera H. Aneurisma infrarrenal de la aorta abdominal. Reporte de un caso. Rev Sanid Milit Mex. 2003:57:173-179.

23. Gutiérrez-Carreño AR, Lizola-Margolis RI, Mendieta-Hernández M. Aneurisma de aorta abdominal micótico roto. Manejo híbrido. Rev Mex Angiol. 2017;45:139-142.

24. Alcántara PA, Cogordan CJ, Reyes BC, Gómez CA, Huerta HD. Tratamiento no quirúrgico del aneurisma disecante de la aorta torácica mediante colocación de implante endovascular. Informe de un caso. Rev Sanid Milit Mex. 2000:54:214-216.

25. Mendoza-Álvarez SA, Fuentes-León J, Vargas-Ayala G, Hernández-González C, López-Arias G, Vera-Lastra O. Síndrome de Marfán, aneurisma toracoabdominal disecado y embarazo. Informe de un caso. Rev Med Inst Mex Seguro Soc. 2009:47:669-672.

26. Cohen-Mussali S, Zerrweck-López C, Rey-Rodríguez A, Valdés-Flores JA, Vidal-González P, Ramírez-Cerda C. Puente carótido-subclavio y prótesis endovascular como manejo híbrido de aneurisma de aorta torácica. An Med Mex. 2013:58:55-59.

27. Díaz-Quiroz G, Archundia-García A, Vázquez-Minero JC, Aceves-Chimal JL. Manejo quirúrgico de aneurisma de aorta ascendente. Presentación de un caso. Rev Esp Med Quir. 2003:8:52-55.

28. Martínez-Tapia AL, Robles-Pérez E, Jiménez-Hernández A, Ramos-Cano VH. Aneurisma disecante de aorta ascendente. A propósito de un caso y revisión de la literatura. Rev Hosp Jua Mex. 2014;81:60-67.

29. Herrera-Gomar M, Alcántara-Meléndez MA, Lomelí-Estrada C, Mendoza-González C, Aguirre-Molina CA, Lorenzo-Negrete JA, et al. Aneurisma de aorta torácica por úlcera aterosclerótica penetrante: tratamiento endovascular, híbrido o cirugía. Revisión. Arch Cardiol Mex. 2009;79:140-146.

30. González-Álvarez CJ, Ordóñez-Toquero G, Rivera-Quintero E. Angioplastía con stent en el tratamiento de coartaciones aórticas críticas. Arch Cardiol Mex. 2006;76:424-430

31. Uruchurtu E, Sánchez A, Pavía A, Hernández I, Valle L, Esquivel M, Medel O, Vargas C. Aortoplastía en coartación aórtica congénita del adulto con balón y prótesis endovascular: resultados inmediatos y seguimiento a 6 meses. Arch Cardiol Mex. 2000;70:72-77.

32. Munayer-Calderón J, Zabal-Cerdeira C, Ledesma-Velazco M, Aldana-Pérez T, Ramírez-Reyes H, Lázaro-Castillo JL. Balloon angioplasty in aortic coarctation: a multicentric study in Mexico. Arch Cardiol Mex. 2002:72:20-28.

33. Fink, G, Gutiérrez VS, Hurtado LLM. Cirugía endovascular mediante el implante de endoprótesis Talent en pacientes adultos con coartación de la aorta torácica: experiencia inicial de cuatro pacientes. Cir Gen. 2002; 24:232-236

34. Hernández-González M, Solorio S, Conde-Carmona I, Rangel-Abundis A, Ledesma M, Munayer J, et al. Intraluminal aortoplasty vs. surgical aortic resection in congenital aortic coarctation. A clinical random study in pediatric patients. Arch Med Res. 2003;34:305-310.

35. Márquéz-González H, De León-Mena S, Yáñez-Gutiérrez L, López-Gallegos D, Camargo-Zettina CO, Ortiz-Vázquez IC, et al. Late complications of aortic coarctation treatment: a Mexican cohort study with more than 10-year follow up. Rev Mex Cardiol. 2015;26:169-173.

36. Zabal C, Attie F, Rosas M, Buendía-Hernández A, García-Montes JA. The adult patient with native coarctation of the aorta: balloon angioplasty or primary stenting? Heart. 2003;89:77-83.

37. Cervantes-Salazar JL, Ramírez-Marroquín S, Benita-Bordes A, Rosas-Peralta M, Attie F. Tratamiento quirúrgico de la coartación de aórtica. Resultados a largo plazo en el Instituto Nacional de Cardiología. Arch Cardiol Mex. 2006;76:63-68.

38. Buenfil-Medina JC, Jiménez-Carbajal MG, Santiago-Herrara R, Fernández-Luna CP. Stent BeGraft Bentley® para tratamiento de coartación aórtica. Arch Cardiol Mex. 2018;88:313-315

39. Maltos-Valdés W, Cáceres-Papadakis GU, Garza-Alatorre AG, Rodríguez-Balderrama I. Miocardiopatía dilatada secundaria a coartación de la aorta. Rev Mex Pediatr. 2004;71:25-27.

40. Rojas DMA, García MA. ¿Es la angioplastía el tratamiento de elección en la coartación de aorta? Presentación de un caso clínico y revisión de la literatura. Med Int Mex. 2010:25:524-529.

41. Rosas MA, Bolio A, Reyes NI, Sienra J. Coartación de la aorta y sibilancias. Bol Med Hosp Infant Mex. 1997;54:241-243.

42. Reyna-Cuevas VM, Segura-Vera L, Borbolla-Sala ME. Angioplastía con stent en coartación aórtica severa, con abordaje por arteria humeral. Salud Tab. 2013;19:66-70.

43. Parra-Bravo JR, Acosta-Valdez JL, Zepeda-Sanabria JR, Beirana-Palencia LG, Rodríguez-Hernández L, Estrada-Loza MJ, et al. Agenesia unilateral de una arteria pulmonar y coartación de aorta en un paciente con síndrome de Turner. Rev Mex Cardiol. 2002;13:162-170. 
44. Guering, EL, Gaspar-Hernández J, González-Pacheco H, Acevedo-Gómez P, Ramírez-Marroquín S, Herrera-Alarcón V, et al. Complicated acute aortic syndromes affecting the descending thoracic aorta: endovascular treatment compared with open repair. Clin Cardiol. 2015;38:585-589.

45. Guering, EL, Gaspar, J, Meléndez-Ramírez, G, Cervantes, J, González-Pacheco, H., Dámas de los Santos, F, et al. Endovascular treatment of type B dissection in patients with Marfan syndrome: mid-term outcomes and aortic remodeling. Cathether Cardiovasc Interv. 2013; 82:E898-E905.

46. Hinojosa CA, Anaya-Ayala JE, Torres-Machorro A, Lizola R, Laparra-Escareno $\mathrm{H}$. Middle aortic syndrome in Takayasu's arteritis: report of two surgical cases. Ann Vasc Surg. 2015;34:e13-e17.

47. Mijangos-Vázquez R, Miranda-Chávez IO, Soto-López ME, Patiño-Bahena EJ, Cano-Zárate R, Covarrubias-Flores AC, et al. Anomalous origin of pulmonary branches from the ascending aorta. A report of five cases and review of the literature. J Cardiol Cases. 2015;11:1-6.

48. Herrera-Gómez Á, Ortega-Gutiérrez C, Luna-Ortiz K, De-León-Zaragoza L. Resección arterial de grandes vasos debido a tumor germinal residual retroperitoneal. Tres casos. Cir Gen. 2011:33:127-131.

49. Fink JG, Fernández SE, Gutiérrez VS, Hurtado LLM, Ruiz DA. Manejo endovascular de la transección de aorta torácica por trauma cerrado de aorta: informe de dos pacientes. Cir Gen. 2002;24:144-147.
50. Sigler-Morales L, Martínez-López C, González-Valenzuela J, Guevara-Saldívar MI, Jaramillo-Talavera J. Fístula aortocava y embolia por proyectil de arma de fuego a la arteria poplítea. Cir Cir. 1997;65: 56-58.

51. Delgadillo GH, Velásquez JA, Fening J, Campos F, Cervantes J, Medina B. Fístula aorto-gástrica. Informe de un caso tratado con reparación de la aorta, gastrectomía total y esófago-yeyuno-anastomosis en $Y$ de Roux. Cir Gen. 2003:25:234-237.

52. Rocha-Rodríguez MG, Rodríguez-Blas Al, Balcázar-Vázquez R, Casian-Castellanos GA, Flores-Cabos AE. Fístula aorto cava asociada con aneurisma de aorta abdominal: reporte de un caso. Rev Hosp Jua Mex. 2010;77:133-137.

53. Vidal-González P, Mussan-Chelminsky G, Kunz-Martínez W, Jonguitud-Bulos V, Rey-Rodríguez A, Cohen-Mussali S. Tratamiento endoluminal para ruptura aórtica por trauma. Reporte de un caso y revisión de la literatura. Cir Cir. 2007;75:297-302.

54. Gamboa R, Ríos-Méndez RE, Solernó R, Giachello F, Videla-Lynch A, Sarmiento RA. Exclusión percutánea de seudoaneurisma aórtico abdominal traumático desde acceso braquial. Arch Cardiol Mex. 2011:82:34-36.

55. López RJA, Parada LJR, Sagahón MJA, Corona PMA, Aguilar AE, Gómez ML, et al. Reparación quirúrgica de doble arco aórtico. Rev Esp Med Quir. 2012;17:210-213. 